\title{
Possible Involvement of Paints Exposure and Smoking on Human Fertility
}

\author{
Rasha F Zahran $^{1 *}$, El-Shahat A Toson ${ }^{1}$ and Salem A Habib ${ }^{1}$ \\ ${ }^{1}$ Chemistry Department (Biochemistry Division), Faculty of Science, Damietta University, Egypt.
}

Received: 24 May 2015 / Accepted: 26 August 2015

*Corresponding author: zahran@du.edu.eg

\begin{abstract}
In parallel with industrial advancements, number of the occupational diseases secondary to chemical exposure is increasing. The chemical agents in the work places affect various organ and tissue systems, leading to chronic diseases including infertility. Therefore, the aim of this study was to determine whether the exposure for paints and smoking can correlate with hormonal and trace element levels or not in order to determine their relationship and significance in male infertility. For these reasons, a hundred and fifty two male painters diagnosed with occupational diseases related to paints exposure in Damietta were included. In addition, forty of the healthy non-exposed and non-smoker males with the same age range to that of the painters were used as controls. The painters were classified into nonsmokers and smokers. The non-smokers were either exposed for paints for less than 15 years (GII) or for more than 15 years (GIII) and the smoker painters were either exposed for less (GIV) or more than 15 years $(\mathrm{GV})$. In sera of the non-smoker painters (GII and GIII) the mean levels of testosterone were lowered by $40.8 \%$ and $51.2 \%$ that of the smoker painters (GIV and GV) were reduced by $44.6 \%$ and $51.5 \%$, respectively, than that of the control. On the other hand, the levels of estradiol $\left(\mathrm{E}_{2}\right)$ in sera of all painters' groups were elevated than that of the control, especially in GIII and GV $(97.1 \%, 138.2 \%$, $117.8 \%$ and $147.6 \%$, respectively). On the other hand, the mean levels of nitric oxide (NO) in sera of the same groups were $328.6 \%, 483.3 \%, 447.6 \%$ and $511.0 \%$ higher than that of the control group, respectively. In addition, the mean serum levels of cadmium $\left(\mathrm{Cd}^{2+}\right)$ were elevated by $55.6 \%, 86.1 \%$, $94.4 \%$, and $119.4 \%$, lead $\left(\mathrm{Pb}^{2+}\right)$ by $90.4 \%, 379.5 \%, 495.9 \%$ and $653.4 \%$, cobalt $\left(\mathrm{Co}^{2+}\right)$ by $140.5 \%$, $153.2 \%, 279.7 \%$ and $406.3 \%$, nickel $\left(\mathrm{Ni}^{2+}\right)$ by $23.3 \%, 33.3 \%, 113.3 \%$ and $123.3 \%$ and copper $\left(\mathrm{Cu}^{2+}\right)$ by $14.6 \%, 22.0 \%, 26.8 \%$ and $63.4 \%$ in GII, GIII, GIV and GV, respectively. In conclusion, the results of this study illustrated that paints' exposure can participate in male infertility possibly via hormonal, heavy metals and nitric oxide-mediated mechanisms..
\end{abstract}

Keywords: Occupational diseases, hormones, infertility, heavy metals and nitric oxide. 


\section{Introduction}

Technically speaking, infertility is the inability to become pregnant after having unprotected sexual intercourse regularly during ovulation for a period of twelve months or more, or the inability to carry a pregnancy to full term. Low sperm count, low motility, malformed sperm, or blocked sperm ducts are among the men problems. Also, men fertility can be adversely affected by exposure to radiation, pesticides, or other environmental poisons [38].

In parallel with industrial advancements, the number of the occupational diseases secondary to chemical exposure is increasing. This work environment usually contains a large number of chemicals, which may be inhaled and absorbed by the body, a process which can affect various organ and tissue systems leading to chronic diseases [47].

\section{1. paints and sex hormones:}

In the last few years, there has been a growing interest and concern for the study of a heterogeneous group of environmental chemicals which may act as endocrine disruptors (EDCs) [23]. Many EDCs are classified as "xenoestrogen" because their action mimics that of estrogen hormones [49]. Multiple lines of evidence from several animal studies indicate that exposure to certain EDCs may drastically alter functional properties of the reproductive, immune, neurologic and endocrine systems [18, 21]. Exposure to environmental toxicants such as copper has been suggested to have adverse effects on male reproduction.

\section{2. heavy metals and fertility:}

It has been hypothesized that exposure to environmental toxicants including heavy metals had been suggested to have adverse effects on male reproduction especially when humans are occupationally and environmentally exposed to their aerosols. $\mathrm{Cd}^{2+}$ is highly toxic metal for humans; it is pervasive in the human environment and accumulates in the human body over a lifetime. The biological half-life of $\mathrm{Cd}^{2+}$ in the human body is estimated to be about $10-20$ years [40]. The concentration of $\mathrm{Cd}^{2+}$ in serum is regarded as the best biological indicator of recent exposure to $\mathrm{Cd}^{2+}$. The majority of information concerning the adverse effects of $\mathrm{Cd}^{2+}$ on male reproductive capacity is related to experimental animal studies while data in human subjects are inconclusive [28]. $\mathrm{Pb}^{2+}$ is inevitably present in the human environment and is known to be toxic agents which accumulate in the human body over a lifetime including male reproductive organs [41]. Epidemiological studies have been equivocal about effects of $\mathrm{Pb}^{2+}$ and $\mathrm{Cd}^{2+}$ on hormone concentrations, male fertility and sperm parameters $[8,39]$.

In 1997, Paksy et al. showed that $\mathrm{Zn+2}$ itself impaired fertility by $20 \%$, while $\mathrm{Cd}+2$ dosedependently blocked the receptivity of female rats. In addition, when $\mathrm{Zn}^{+2}$ and $\mathrm{Cd}^{+2}$ were added to the culture medium of ovarian granulosa cells $\mathrm{Cd}^{+2}$ suppressed follicle-stimulating-hormone(FSH-) and cAMP-stimulated progesterone accumulation [34]. [36] added that, the reduction in fertility at low exposure levels of $\mathrm{Pb} 2+$ could be explained by occupational exposure to solvents. In the time-to-pregnancy study among men exposed to organic solvents, however, occupational exposure to these agents was only suggestively associated with reduced fecund ability [37]. In addition, [36] reported that, the association between $\mathrm{Pb} 2+$ exposure and reduced fertility seemed to be stronger in older age groups. A similar finding was made in the Danish study [9] which showed that, exposure to $\mathrm{Pb} 2+$ was associated with reduced fertility among older men but not among younger men (cutoff point at 30 years of age) in a subset of battery workers with at least $[\mathrm{Pb} 2+]>20 \mu \mathrm{g} / \mathrm{dl}$. [44] added that the mechanisms by which $\mathrm{Zn}^{+2}$ and $\mathrm{Cd}^{+2}$ can affect FSH-stimulated progesterone production seem to be different.

Cobalt is a suspected reproductive toxicant and exposure to it has the potential to negatively affect the human reproductive system. Cobalt is used in alloys, batteries, pigments, coloring agents, electroplating, production of other chemicals and in various other applications. Studies in mice showed a decrease of sperm motility and/or an increase of abnormal sperm cells after inhalation, acute exposure, or dietary administration of [10].

\subsection{Nitric oxide and fertility:}

[4] showed that NO are implicated in the steroid hormones binding to albumin thus affecting free hormonal fractions a phenomenon which can explain somewhat the pathophysiological role NO and other free radicals in different steroidhormones related diseases including human infertility. 
NO is a free radical and a highly reactive central mediator in biological systems which is generated by NO synthase (NOS) [7]. Several studies have shown that this enzyme is associated with acrosome and tails of human sperm and it appears to be involved in sperm motility and acrosomal reaction that are the main factors in fertilization process [24,14]. In addition, [19] observed a significantly decreased in sperm motility and a significantly increased MDA, nitrite, and nitrate concentrations in the sperm of normozoospermic smokers in comparison with non-smoker men.

Several reports support the negative effect of cigarette smoke on sperm motility in a concentration- and time-dependent manner [11, 26]. However, the literature concerning the effects of cigarette smoking and/or paints on sex hormones, thyroid stimulating hormone (TSH), heavy metals accumulation and NO concentration in fertile smoking men is limited. Therefore, the aim of this work was to illustrate if the exposure to paints and/or smoking can participate in human infertility or not.

\section{Subjects and Methods}

\subsection{Subjects:}

This study was conducted on 152 male painters with an age range of $16-58$ years. The painters were collected from Elshoaraa, Elsinania and Elrawda regions, Damietta Governorate, Egypt. A group of 40 healthy males in the same age range were taken as controls. All individuals know the nature of the research and gave samples with consent.

The 152 painters were classified into non-smokers (GII and GIII) and smokers (GIV and GV). These painters were either exposed for paints for less than 15 years (GII and GIV) or for more than 15 years (GIII and GV), respectively.

\subsubsection{Preparation of the blood samples:}

$3.0 \mathrm{ml}$ of venous blood were collected from each painter and control subject and were left to clot at room temperature. After clotting, the samples were centrifuged and the serum samples were separated and stored at $-80^{\circ} \mathrm{C}$ until their use.

\subsection{Methods:}

\subsubsection{Enzyme-linked immuno-sorbent assay (ELISA):}

A one-step enzyme linked immunosorbent assay (ELISA) was used for determination of testosterone according to the method of Marcus [31], Joshi et al., [27] and Ekins [17]. Also, E2 was determined by ELISA according to the method of Tsang et al., [42] and Gore-langton and Armstrong [20]. In addition, TSH was determined by ELISA according to the method of Hopton et al., [25].

\subsubsection{Colorimetric assays:}

NO level was determined by the method of Montgomery et al., [33].

\subsubsection{Atomic absorption:}

Cadmium, lead, cobalt, nickel and copper were determined in serum by atomic absorption spectrophotometer (Buck Scientific Accusys 211) according to the method of Rosner and Gorfien [35].

\section{3-Results and discussions:}

\subsection{Serum testosterone levels:}

The mean level of testosterone of the healthy control was $26.0 \pm 1.1 \mathrm{nmol} / \mathrm{l}(\mathrm{n}=24)$ but that of the non-smoker painters with less than 15 years of exposure (GII) was15.4 $\pm 1.94 \mathrm{nmol} / \mathrm{l}(\mathrm{n}=36)$. In addition, the non-smoker painters of GIII showed a mean testosterone level of $12.7 \pm 1.85 \mathrm{nmol} / \mathrm{l}$ $(n=30)$. Generally, the mean levels of testosterone of the non-smoker painters (GII and GIII) were highly significantly decreased $(\mathrm{p}<0.001)$ when compared with that of healthy control (Table 1).

The mean level of testosterone of the smoker painters with exposure time of less than 15 years (GIV) was $14.4 \pm 2.4 \mathrm{nmol} / \mathrm{l}(\mathrm{n}=27)$ but that of the painters who exposed for more than 15 years $(\mathrm{GV})$ was $12.6 \pm 2.17 \mathrm{nmol} / \mathrm{l} \quad(\mathrm{n}=27)$. Statistically, the mean testosterone levels of the smoker groups were highly significantly decreased $(p<0.001)$ than that of the control one (Table 1).

Normally, LH stimulates the testis to produce testosterone which stimulates testicular spermatogenesis [12]. Therefore, the reduction in serum testosterone levels of the painters who 
exposed for both paints and cigarettes smoke may cause defects in the process of spermatogenesis and thence infertility. In addition, [15] showed that in correlation with LH and FSH gonadotropins, testosterone in men regulates the sexual functioning and controls sexual desire, sexual development, and semen production and maturation in the testes. Therefore, the long term exposure to cigarrate smoke and paints, in this study, can cause chronic alterations of E2 and testosterone hormones and thence can harm both physical and sexual aspects of male anatomy including erectile dysfunction, low sperm production, and finally poor male fertility.

\subsection{Estradiol level:}

The mean level of $\mathrm{E}_{2}$ of the healthy control (group I) was $51.0 \pm 6.8 \mathrm{pg} / \mathrm{ml}(\mathrm{n}=21)$. Also, the level of $\mathrm{E}_{2}$ of the non-smoker painters who were exposed for less than 15 years (GII) was $100.5 \pm 11.9 \mathrm{pg} / \mathrm{ml}$ $(n=18)$ and that of whom who were exposed for more than 15 years (GIII) was $121.5 \pm 13.6 \mathrm{pg} / \mathrm{ml}$ $(n=26)$. The statistical calculations of the latter mean values showed that the level of $\mathrm{E}_{2}$ hormone was greatly and significantly elevated than that of the control group (Table 1).

With respect to the $E_{2}$ levels of the smoker painters (GIV and GV), it showed higher elevation in GV than that of GIV (mean=111.1 $\pm 13.9 \mathrm{pg} / \mathrm{ml}$ and
$126.3 \pm 12.3 \mathrm{pg} / \mathrm{ml}$, respectively when compared with that of the healthy control $(\mathrm{p}<0.001)$ (Table $1)$.

In addition, E2 has been shown to directly affect steroidogenesis in the rat testis via accumulation of estrogen-regulated proteins [43]. Therefore, one can expect that the elevation of E2 levels in sera of the painters included in this study may stimulates Leydig cell hyperplasia which has been associated with cryptorchidism, testicular damage, and impaired spermatogenesis as was previously reported by [1] who found association between E2 level and Leydig cell hyperplasia in rodents. Since $[44,16]$ demonstrated that, circulating $\mathrm{LH}$ and FSH concentrations were effectively reduced by E2, therefore, the feedback mechanism of the elevated level of E2 in this study can amplify the reduction of testosterone level possibly via $\mathrm{LH}$ and FSH mediated mechanism. This finding confirm that of [46] who found that paint thinner exposure for 15 days had decreased serum LH and testosterone concentrations in a parallel manner.

In addition to the effect of paints, the results of the present study confirm the negative effect of cigarette smoke on human fertility at least in part via reduction of serum testosterone level or via its negative effect on sperm motility in a concentration- and time-dependent manner. Somewhat similar results were previously reported by $[11,26]$.

Table 1: The mean serum levels of testosterone and $E_{2}$ of non-smoker and smoker painters who were exposed for paints either for less than 15 years or for more than 15 years compared to those of the healthy control.

\begin{tabular}{|c|c|c|c|c|}
\hline \multirow{2}{*}{$\underbrace{\text { Parameter }}_{\text {Group }}$} & \multicolumn{2}{|c|}{ Non-Smokers painters } & \multicolumn{2}{|c|}{ Smokers painters } \\
\hline & $\begin{array}{c}\text { Testosterone } \\
(\mathrm{nmol} / \mathrm{l})\end{array}$ & $\begin{array}{c}\text { Estradiol }\left(\mathbf{E}_{2}\right) \\
(\mathrm{pg} / \mathrm{ml})\end{array}$ & $\begin{array}{c}\text { Testosterone } \\
(\mathrm{nmol} / \mathrm{l})\end{array}$ & $\begin{array}{c}\text { Estradiol }\left(\mathbf{E}_{2}\right) \\
(\mathrm{pg} / \mathrm{ml})\end{array}$ \\
\hline $\begin{array}{l}\text { Control } \\
\text { Mean } \pm \text { S.E } \\
n\end{array}$ & $\begin{array}{l}26.0 \pm \\
24\end{array}$ & 51.0 & $\begin{array}{l}26.0 \\
24\end{array}$ & $51.0 \pm 6.8$ \\
\hline $\begin{array}{l}\text { Less than } 15 \text { year } \\
\text { Mean } \pm \text { S.E } \\
n \\
\text { Percent }\end{array}$ & $\begin{array}{l}15.4 \pm 1.94^{* * *} \\
36 \\
{[40.8 \%]^{\mathrm{a}}}\end{array}$ & $\begin{array}{l}100.5 \pm 11.9^{* * *} \\
18 \\
{[97.1 \%]^{\mathrm{b}}}\end{array}$ & $\begin{array}{l}14.4 \pm 2.4^{* * *} \\
27 \\
{[44.6 \%]^{\mathrm{a}}}\end{array}$ & $\begin{array}{l}111.1 \pm 13.9^{* * *} \\
18 \\
{[117.8 \%]^{\mathrm{b}}}\end{array}$ \\
\hline $\begin{array}{l}\text { More than } 15 \text { year } \\
\text { Mean } \pm \text { S.E } \\
n \\
\text { Percent }\end{array}$ & $\begin{array}{l}12.7 \pm 1.85^{* * *} \\
30 \\
{[51.2 \%]^{\mathrm{a}}}\end{array}$ & $\begin{array}{l}121.5 \pm 13.6^{* * *} \\
26 \\
{[138.2 \%]^{\mathrm{b}}}\end{array}$ & $\begin{array}{l}12.6 \pm 2.17^{* * *} \\
27 \\
{[51.5 \%]^{\mathrm{a}}}\end{array}$ & $\begin{array}{l}126.3 \pm 12.3^{* * *} \\
26 \\
{[147.6 \%]^{\mathrm{b}}}\end{array}$ \\
\hline
\end{tabular}

- Values were expressed as mean \pm Standard error (S.E) in each case.

$*=$ Significant, $* *=$ very significant and $* * *=$ extremely significant when compared with the corresponding values of control.

[]$^{\mathrm{a}}=$ Percent of reduction and []$^{\mathrm{b}}=$ Percent of elevation than those of the control.

[]$^{\mathrm{a}} \&[]^{\mathrm{b}}=($ Mean of the control - Mean of the tested group $) /$ Mean of the control.

\subsection{Thyroid stimulating hormone (TSH):}

The statistical analysis of the results showed that the mean level of thyroid-stimulating 
hormone (TSH) of the GII, GIII, GIV and GV were highly significantly increased $(\mathrm{p}<0.001)$ when compared with that of healthy control group (Table 2).

\subsection{Heavy metals:}

The mean serum levels of $\mathrm{Cd}^{2+}$ were elevated by $55.6 \%, 86.1 \%, 94.4 \%$, and $119.4 \%$, lead by $90.4 \%, 379.5 \%, 495.9 \%$ and $653.4 \%$, cobalt by $140.5 \%, 153.2 \%, 279.7 \%$ and $406.3 \%$, nickel by $23.3 \%, 33.3 \%, 113.3 \%$ and $123.3 \%$ and copper by $14.6 \%, 22.0 \%, 26.8 \%$ and $63.4 \%$ in GII, GIII, GIV and GV, respectively (Table 3).

In our results, the mean levels of_Cd ${ }^{2+}$ in nonsmoker painters (GII and GIII) were significant increased compared to GI. These results showed that paints can cause elevation of serum $\mathrm{Cd}^{2+}$ ions. In addition to the effect of paints, the results of the present study confirm the effect of cigarette smoke on serum $\mathrm{Cd}^{2+}$ levels this is because smoker painters (GIV and GV) showed very significant increases in their mean serum contents of $\mathrm{Cd}^{2+}$ than those of the non-smokers. Therefore these results confirm those of [13] at least in part on the effect of cigarette smoke-years on blood_Cd ${ }^{2+}$ on both sperm density and sperm volume, especially in heavy smokers. Based on these results, one can add that $\mathrm{Cd}^{2+}$, which is present in cigarettes, could be a possible causative agent for lowering sperm density among smoker's painters. Unfortunately, the seminal parameters were not evaluated in the present study but the reduction in serum testosterone and the elevation of E2 mean levels after exposure to cigarette smoke and/or paints are direct evidence of testicular damage. This is because [32], found low sperm count, sperm motility, sperm maturity, and lowered level of testosterone during administration of a high dose of $\mathrm{Cd}^{2+}$ to the mice and attributed their finding to the severe necrosis and atrophy in the testis of the high dose exposed group, a process which showed no successful mating in such group. These authors concluded that, $\mathrm{Cd}^{2+}$ affects male reproductive system activity and can cause infertility in mice as an animal model. Moreover, calcium $\left(\mathrm{Ca}^{2+}\right)$ channels are susceptible to $\mathrm{Cd}^{2+}$ poisoning and potassium $\left(\mathrm{K}^{+}\right)$channels to $\mathrm{Pb}^{2+}$. These channel isoforms have been identified in human testes and spermatozoa and not only offer entry paths for metallic toxicants into mature spermatozoa but also are involved in the early events of acrosome reactions [8]. Therefore, this may be one of the mechanisms by which the excessive levels of both $\mathrm{Cd} 2+$ and $\mathrm{Pb} 2+$ in this study can contribute to human infertility. In addition, the outhers render the deleterious effect of $\mathrm{Cd} 2+$ and other heavy metal ions on spermatogenesis to be mediated through their effects on reducing ascorbic acid level which finally induced oxidative damage on rat testis [29]. Also, [44] added that $\mathrm{Zn} 2^{+}$itself impaired fertility by $20 \%$, while $\mathrm{Cd}^{2+}$ dosedependently blocked the receptivity of female rats. They also added that, when $\mathrm{Zn}^{2+}$ and $\mathrm{Cd}^{2+}$ were added to the culture medium of ovarian granulosa cells, $\mathrm{Cd}^{2+}$ suppressed FSH- and cAMPstimulated progesterone accumulation. This may be one of the infertility mechanisms which can be involved in this study at least in part by reducing testosterone level via the reduced FSH level. Also, no protective effect of $\mathrm{Zn}$ against $\mathrm{Cd}^{+2}$-induced drop in progesterone production but $\mathrm{Zn}^{+2}$ by itself induced a significant increase in FSH-supported progesterone synthesis. On the other hand, $\mathrm{Zn}^{+2}$ by itself are not able to induce significant increase in FSH-supported progesterone synthesis. The authors concluded that, while $\mathrm{Zn}$ protected against Cd-induced sterility in vivo, it failed to counteract the direct effect of $\mathrm{Cd}$ on steroid biosynthesis.

[45] showed that the relationship between the increase in urinary $\mathrm{Ni}$ and the increase in plasma FSH may depends on the action of the former, even at low doses, on the hypothalamic-pituitarygonadal axis. The increases in serum $\mathrm{Ni}$ in this study confirm the previous findings.

[22], found that, hyperthyroidism or hypothyroidism are associated with altered fertility due to changes in the levels and activities of hormones of the brain-pituitary-gonadal axis. [22], added that, multifactorial control of reproduction invariably involves regulation of metabolism by a number of hormones including $\mathrm{TSH}$, which are known to have profound effect on body metabolism, growth and development. Also, there are various reports indicating that thyroid hormones interact with the hormones of brainpituitary-gonadal axis. [30], added that normal thyroid function is important for normal regulation of reproduction. Based on the results of the present study, it was suggested that the increase in the mean heavy metals levels not only directly participate in human infertility via inhibiting sex hormones but also through their indirect effect which include thyroid hormones or their trophic hormone; namely, TSH. The increase in the mean level of TSH with simultaneous reductions in the mean levels of testosterone and the results of [5] which showed that urinary cadmium was associated with increases in both $\mathrm{T} 3$ and $\mathrm{T} 4$ [2] confirms the previous suggestion. 
The $\mathrm{Cu} / \mathrm{Zn}$ ratio in seminal plasma was significantly $(\mathrm{p}<0.01)$ higher in controls compared with oligozoospermic and azoospermic patients [3]. [6] added that, copper administration to rats caused a significant damage to seminiferous tubules diameter, spermatogonial cells nuclei diameter, sertoli cells nuclei diameter and epithelial height compared to the non-exposed rats.

Table 2: The mean serum levels of TSH and nitric oxide of non-smoker and smoker painters who were exposed for paints either for less than 15 years or for more than 15 years compared to those of the healthy control.

\begin{tabular}{|c|c|c|c|c|}
\hline \multirow{2}{*}{ Group } & \multicolumn{2}{|c|}{ Non-Smokers painters } & \multicolumn{2}{|c|}{ Smokers painters } \\
\hline & TSH & Nitric oxide & TSH & Nitric oxide \\
\hline $\begin{array}{l}\text { Control } \\
\text { Mean } \pm \text { S.E } \\
n\end{array}$ & $\begin{array}{l}1.0 \pm 0.18 \\
17\end{array}$ & $\begin{array}{l}4.2 \pm 0.25 \\
28\end{array}$ & $\begin{array}{l}1.0 \pm 0.18 \\
17\end{array}$ & $\begin{array}{l}4.2 \pm 0.25 \\
28\end{array}$ \\
\hline $\begin{array}{l}\text { Less than } 15 \text { year } \\
\text { Mean } \pm \text { S.E } \\
n \\
\text { Percent }\end{array}$ & $\begin{array}{l}2.79 \pm 0.36^{* * *} \\
24 \\
{[179.0 \%]^{\mathrm{a}}}\end{array}$ & $\begin{array}{l}18.0 \pm 1.6^{* * *} \\
35 \\
{[328.6 \%]^{\mathrm{a}}}\end{array}$ & $\begin{array}{l}5.6 \pm 0.57^{* * *} \\
21 \\
{[460.0 \%]^{\mathrm{a}}}\end{array}$ & $\begin{array}{l}23.0 \pm 1.5^{* * *} \\
21 \\
{[447.6 \%]^{\mathrm{a}}}\end{array}$ \\
\hline $\begin{array}{l}\text { More than } 15 \text { year } \\
\text { Mean } \pm \text { S.E } \\
n \\
\text { Percent }\end{array}$ & $\begin{array}{l}4.4 \pm 0.53^{* * *} \\
33 \\
{[340.0 \%]^{\mathrm{a}}}\end{array}$ & $\begin{array}{l}24.5 \pm 2.2^{* * *} \\
26 \\
{[483.3 \%]^{\mathrm{a}}}\end{array}$ & $\begin{array}{l}5.98 \pm 0.77^{* * *} \\
27 \\
{[498.0 \%]^{\mathrm{a}}}\end{array}$ & $\begin{array}{l}25.7 \pm 1.9^{* * *} \\
42 \\
{[511.9 \%]^{\mathrm{a}}}\end{array}$ \\
\hline
\end{tabular}

- Values were expressed as mean \pm Standard error (S.E) in each case.

$*=$ Significant, $* *=$ very significant and $* * *=$ extremely significant when compared with the corresponding values of control.

[]$^{\mathrm{a}}=$ Percent of reduction and []$^{\mathrm{b}}=$ Percent of elevation than those of the control.

[]$^{\mathrm{a}} \&[]^{\mathrm{b}}=($ Mean of the control - Mean of the tested group $) /$ Mean of the control.

Table 3: The mean serum levels of cadmium, lead, cobalt, nickel and copper of non-smoker and smoker painters who were exposed for paints either for less than 15 years or for more than 15 years compared to those of the healthy control.

\begin{tabular}{|c|c|c|c|c|c|}
\hline \multirow{2}{*}{ Group } & \multicolumn{2}{|c|}{ Less than 15 year } & \multicolumn{2}{|c|}{ More than 15 year } & \multirow{2}{*}{ control } \\
\hline & Non-Smokers & Smokers & Non-Smokers & Smokers & \\
\hline $\begin{array}{l}\text { Cadmium } \\
\text { Mean } \pm \text { S.E } \\
n \\
\text { Percent }\end{array}$ & $\begin{array}{l}0.56 \pm 0.06^{*} \\
20 \\
{[55.6 \%]^{\mathrm{b}}}\end{array}$ & $\begin{array}{l}0.7 \pm 0.09^{* *} \\
14 \\
{[94.4 \%]^{\mathrm{b}}}\end{array}$ & $\begin{array}{l}0.67 \pm 0.096^{*} \\
18 \\
{[86.1 \%]^{\mathrm{b}}}\end{array}$ & $\begin{array}{l}0.79 \pm 0.07^{* *} \\
24 \\
{[119.4 \%]^{\mathrm{b}}}\end{array}$ & $\begin{array}{l}0.36 \pm 0.06 \\
12\end{array}$ \\
\hline $\begin{array}{l}\text { Lead } \\
\text { Mean } \pm \text { S.E } \\
n \\
\text { Percent }\end{array}$ & $\begin{array}{l}27.8 \pm 5.8^{*} \\
22 \\
{[90.4 \%]^{\mathrm{b}}}\end{array}$ & $\begin{array}{l}87.0 \pm 14.9^{* * *} \\
17 \\
{[495.9 \%]^{\mathrm{b}}}\end{array}$ & $\begin{array}{l}70.0 \pm 8.0^{* * *} \\
18 \\
{[379.5 \%]^{\mathrm{b}}}\end{array}$ & $\begin{array}{l}110 \pm 15.9^{* * * *} \\
14 \\
{[653.4 \%]^{\mathrm{b}}}\end{array}$ & $\begin{array}{l}14.6 \pm 2.5 \\
18\end{array}$ \\
\hline $\begin{array}{l}\text { Cobalt } \\
\text { Mean } \pm \text { S.E } \\
n \\
\text { Percent } \\
\end{array}$ & $\begin{array}{l}1.9 \pm 0.1^{* * * *} \\
16 \\
{[140.5 \%]^{\mathrm{b}}}\end{array}$ & $\begin{array}{l}3.0 \pm 0.87^{*} \\
13 \\
{[279.7 \%]^{\mathrm{b}}}\end{array}$ & $\begin{array}{l}2.0 \pm 0.36^{* *} \\
16 \\
{[153.2 \%]^{\mathrm{b}}}\end{array}$ & $\begin{array}{l}4.0 \pm 0.4^{* * *} \\
12 \\
{[406.3 \%]^{\mathrm{b}}}\end{array}$ & $\begin{array}{l}0.79 \pm 0.14 \\
20\end{array}$ \\
\hline $\begin{array}{l}\text { Nickel } \\
\text { Mean } \pm \text { S.E } \\
n \\
\text { Percent }\end{array}$ & $\begin{array}{l}3.7 \pm 0.75 \\
14 \\
{[23.3 \%]^{b}}\end{array}$ & $\begin{array}{l}6.4 \pm 1.5 \\
10 \\
{[113.3 \%]^{\mathrm{b}}}\end{array}$ & $\begin{array}{l}4.0 \pm 0.87 \\
15 \\
{[33.3 \%]^{\mathrm{b}}}\end{array}$ & $\begin{array}{l}6.7 \pm 0.84^{* *} \\
12 \\
{[123.3 \%]^{\mathrm{b}}}\end{array}$ & $\begin{array}{l}3.0 \pm 0.66 \\
10\end{array}$ \\
\hline $\begin{array}{l}\text { Copper } \\
\text { Mean } \pm \text { S.E } \\
n \\
\text { Percent }\end{array}$ & $\begin{array}{l}4.7 \pm 0.87 \\
18 \\
{[14.6 \%]^{b}}\end{array}$ & $\begin{array}{l}5.2 \pm 0.5 \\
19 \\
{[26.8 \%]^{\mathrm{b}}}\end{array}$ & $\begin{array}{l}5.0 \pm 0.59 \\
15 \\
{[22.0 \%]^{\mathrm{b}}}\end{array}$ & $\begin{array}{l}6.7 \pm 1.2 \\
16 \\
{[63.4 \%]^{b}}\end{array}$ & $\begin{array}{l}4.1 \pm 0.45 \\
30\end{array}$ \\
\hline
\end{tabular}

- Values were expressed as mean \pm Standard error (S.E) in $\mu \mathrm{g} / \mathrm{dl}$ each case.

$*=$ Significant, $* *=$ very significant and $* * *=$ extremely significant when compared with the corresponding values of control.

$[\mathrm{a}=$ Percent of reduction and $[\mathrm{b}=$ Percent of elevation than those of the control.

[ ]a $\&[$ ] $b=($ Mean of the control - Mean of the tested group)/Mean of the control.

\subsection{Nitric oxide:}

The mean level of nitric oxide of the healthy control (group I) was $4.2 \pm 0.25 \mu \mathrm{mol} / \mathrm{l}(\mathrm{n}=28)$.
In the non-smoker painters (less than 15 years, group II), the mean level of nitric oxide was 18.0 $\pm 1.6 \mu \mathrm{mol} / \mathrm{l}(\mathrm{n}=35)$. In addition, the non-smoker painters (more than 15 years, group III) showed a 
mean value of nitric oxide of $24.5 \pm 2.2 \mu \mathrm{mol} / \mathrm{l}(\mathrm{n}$ $=26$ ).

The mean values of nitric oxide of the GII and GIII were highly significantly increased $(\mathrm{p}<0.001)$ when compared with that of the healthy control group (Table 2).

The mean level of nitric oxide of the smoker painters (less than 15 years, GIV) was $23.0 \pm 1.5$ $\mu \mathrm{mol} / \mathrm{l}(\mathrm{n}=21)$. Also, a higher level of nitric oxide was found in sera of the smoker painters (more than 15 years, GV) $25.7 \pm 1.9 \mu \mathrm{mol} / \mathrm{l}(\mathrm{n}=42)$.

The mean values of nitric oxide of the GIV and GV were highly significantly increased $(\mathrm{p}<0.001)$ when compared with that of healthy control (Table 2).

[48], showed NO plays a crucial role in reproduction at every level in the organism. In the brain, it activates the release of luteinizing hormone-releasing hormone (LHRH). The axons of the LHRH neurons project to the mating centers in the brain stem.

\section{4-Correlation:}

\subsection{Nitric oxide and hormones:}

Nitric oxide has a positive correlation with estradiol $(\mathrm{r}=0.2888, \quad \mathrm{p}<0.0028)$ and TSH $(\mathrm{r}=0.3200, \mathrm{p}=0.0004)$.
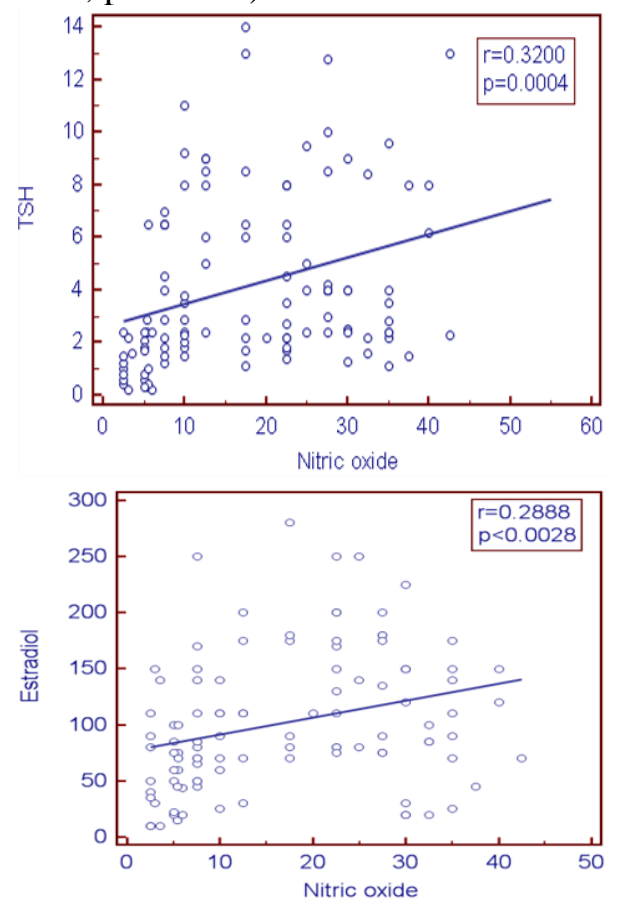

\subsection{Nitric oxide and heavy metals:}

Nitric oxide has a positive correlation with copper $(\mathrm{r}=0.2223, \mathrm{p}=0.0304)$ and lead $(\mathrm{r}=0.552$, $\mathrm{p}<0.0001)$.
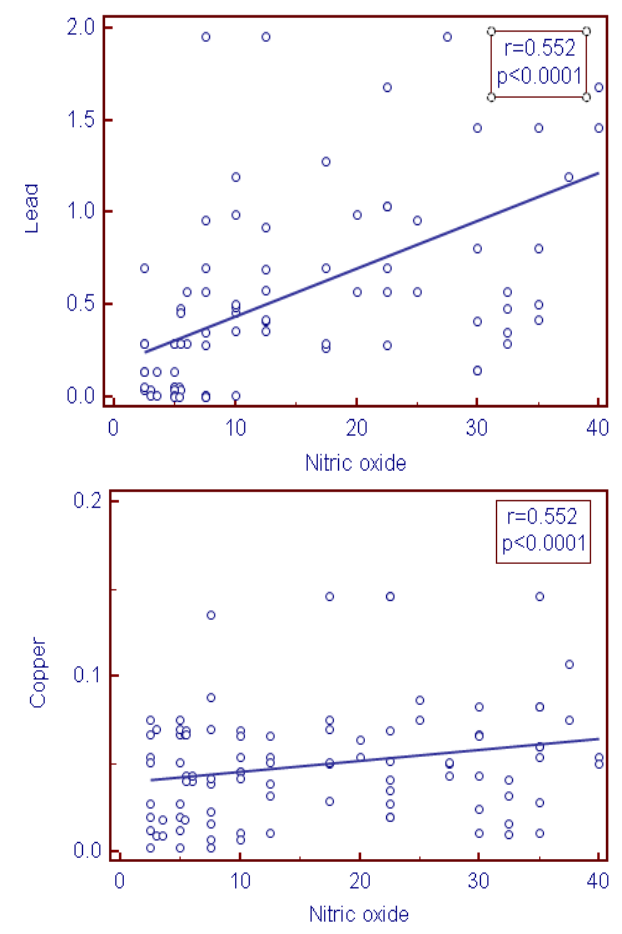

\subsection{Heavy metals and hormones:}

Cadmium was negatively correlated with testosterone ( $\mathrm{r}=-0.2468, \mathrm{p}=0.0263)$. In addition, lead was positively correlated with TSH $(\mathrm{r}=0.3709, \mathrm{p}=0.0006)$.
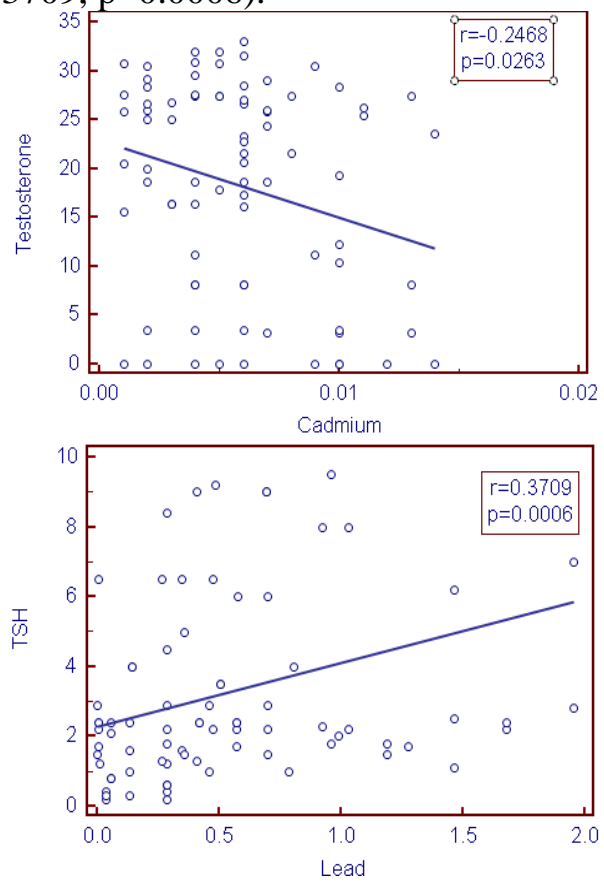


\section{References}

A. Calogero, R. Polosa, A. Perdichizzi, F. Guarino, S. La Vignera, A. Scarfia, et al., Cigarette smoke extract immobilizes human spermatozoa and induces sperm apoptosis. Reprod. Biomed. Online. 19 (4) (2009) 564-71.

A. Kasperczyk, M. Dziwisz, Lead and cadmium influence on semen parameters. Ginekol Pol. 73 (2002) 449-53.

A.K. Harding, G.P. Daston, G.R. Boyd, G.W. Lucier, S.H. Safe, J. Stewart, D.E. Tillitt, G. Van Der Kraak, Endocrine disrupting chemicals research program of the U.S. Environmental Protection Agency: summary of a peer-review report, Health Perspect. 114 (2006) 1276-1282.

ATSDR, Draft Toxicological Profile for Uranium U.S. Department of Health and Human Services, Public Health Service, Agency for Toxic Substances and Disease Registry (2011).

B. Yilmaz, S. Kutlu, S. Canpolat, S. Sandal, A. Ayar, R. Mogulkoc, H. Kelestimur, Effects of paint thinner exposure on serum LH, FSH and testosterone levels and hypothalamic catecholamine contents in the male rat, Biol. Pharm. Bull. 24 (2001) 163-166.

B.K. Tsang, D.T. Armstrong, J.F. Whitfield, Steroid biosynthesis by isolated human ovarian follicular cells in vitro, J. clin. Endocrinol. Metab. 51 (1980) 1407-1411.

B.M. Herrero, S. Chatterjee, L. Lefievre, E. de Lamirande, C. Gagnon, Nitric oxide interacts with the cAMP pathway to modulate capacitation of human spermatozoa, Free Radic. Biol. Med. 29 (6) (2000) 522-36.

D. Kini, Rekhan, A.K. Nayanatara, C. Ramswamy, Pai, R. Sheila, Bhat, M. Ramesh, Mantur, S. Venkappa, Infertility in male wistar rats induced by cadmium chloride: role of ascorbic acid, Journal of Chinese Clinical Medicine. 4 (11) ( 2009) 616.

E. Tanrıkut, A. Karaer, O. Celik, E. Celik, B. Otlu, E. Yilmaz and O. Ozgul, "Role of endometrial concentrations of heavy metals (cadmium, lead, mercury and arsenic) in the aetiology of unexplained infertility", European Journal of Obstetrics \& Gynecology and Reproductive Biology. 179 (2014) 187-190.

F. Rosner, P.C. Gorfien, Erythrocytes and Plasma Zinc and magnesium levels in health and disease, J. Lab. and Clin. Med. 72 (1968) 213-219.

G.E. Krassas, K. Poppe, D. Glinoer, Thyroid function and human reproductive health, Endocr. Rev. 31 (2010) 702-755.

G.J. Marcus, et al., A simple linked immunoassay for testosterone, Steroids 46 (1985) 975.

H. Babaei, R. Kheirandish, L. Ebrahimi, The effects of copper toxicity on histopathological and morphometrical changes of the rat testes, Asian Pacific Journal of Tropical Biomedicine. 2 (3) (2012) S1615-S1619.

H. Yılmaz, A. Keten, E. Karacaoğlu, E. Tutkun, R. Akçan, Analysis of the hematological and biochemical parameters related to lead intoxication, Journal of Forensic and Legal Medicine. 19 (8) (2012) 452-454.

H.A.C. Montgomery, J.F. Dymock, The determination of nitrate in water, Analyst, 86 (1961) 414-416.

H.R. Habibi, E.R. Nelson, E.R.O. Allan, New insights into thyroid hormone function and modulation of reproduction in goldfish, General and Comparative Endocrinology. 175 (1) (2012) 19-26.

J. Bonde, H. Kolstad, Fertility of Danish battery workers exposed to lead. Int J Epidemiol 26 (1997) 1281-1288.

J. Zhou, Z.H. Cai, X.S. Zhu, Endocrine disruptors: an overview and discussion on issues surrounding their impact on marine animals, J. Mar. Anim. Ecol. 2 (2009) 7-12.

J.R. Bucher, M.R. Elwell, M.B. Thompson et al. Inhalation toxicity studies of cobalt sulfate in F344/N rats and B6C3F1 mice, Fundam Appl Toxicol. 15 (1990) 357.

K. Paksy, K. Rajczy, ZS. Forgacs, P. Lazar, A. Bernard, I. Gati, G.S. Kaali, Effect of cadmium on morphology and steroidogenesis of cultured human ovarian granulosa cells, J. Appl. Toxicol. 17 (1997) 321-327.

K.J. Turner, M. Morley, N. Atanassova, I.D. Swanston, R.M. Sharpe, Effect of chronic administration of an aromatase inhibitor to adult male rats on pituitary and testicular function and fertility, J. Endocrinol. 164 (2000) 225-238.

L. Fusani, D. Della Seta, F. Dessì-Fulgheri, F. Farabollini, Altered reproductive success in rat pairs after environmental-like exposure to xenoestrogen, Proc. R. Soc. 274 (2007) 1631-1636.

M. Monsefi, S. Alaee, A. Moradshahi, L. Rohani, Cadmium-induced infertility in male mice, Environ. Toxicol. 25 (2010) 94-102.

M. R. Hopton et al., Clinical chemistry, 32 (1986) 691.

M. Sallmén, M.L. Lindbohm, A. Anttila, P. Kyyrönen, H. Taskinen, E. Nykyri, K. Hemminki, Time to pregnancy among the wives of men exposed to organic solvents. Occup Environ Med. 55 (1998) 24-30.

M. Sallmén, M.L. Lindbohm, M. Nurminen, Paternal exposure to lead and infertility, Epidemiology. 11 (2000) 148-152.

M.A. Ghaffari, M. Rostami, Lipid peroxidation and nitric oxide levels in male smokers' spermatozoa and their relation with sperm motility, J. Reprod. Infertil. 13(2) (2012) 81-87. 
M.H. Tong, L.K. Christenson, W.C. Song, Aberrant cholesterol transport and impaired steroidogenesis in Leydig cells lacking estrogen sulfotransferase, Endocrinology 145 (2004) 2487-2497.

O. Akinloye, A.O. Arowojolu, O.B. Shittu, J.I. Anetor, Cadmium toxicity: a possible cause of male infertility in Nigeria, Reproductive biology. 6 (1) (2006) 17-30.

O. Akinloye, F.M. Abbiyesuku, O.O. Oguntibeju, A.O. Arowojolu, E.J. Truter, The impact of blood and seminal plasma zinc and copper concentrations on spermogram and hormonal changes in infertile Nigerian men, Reproductive Biology. 11 (2) (2011) 83-97.

P. Grandjean, D. Bellinger, A. Bergman, S. Cordier, G. Davey-Smith, B. Eskenazi, D. Gee, K. Gray, M. Hanson, P. van den Hazel, J.J. Heindel, B. Heinzow, I. Hertz-Picciotto, H. Hu, T.T. Huang, T.K. Jensen, P.J. Landrigan, I.C. McMillen, K. Murata, B. Ritz, G. Schoeters, N.E. Skakkebaek, S. Skerfving, P. Weihe, The faroes statement: human health effects of developmental exposure to chemicals in our environment, Basic Clin. Pharmacol. Toxicol. 102 (2008) 73-75.

P.C. Champe, R.A. Harvey D.E. Ferrier Lippincott Illustrated Reviews, (3rd edn). Lippincott Williams \& Wilkins. 351 West Camden Street Baltimore, MD 21201. (2005) 238.

P.H. Hung, L. Froenicke, C.Y. Lin, L.A. Lyons, M.G. Miller, K.E. Pinkerton, et al., Effects of environmental tobacco smoke in vivo on rhesus monkey semen quality, sperm function and sperm metabolism, Reprod Toxicol. 27(2) (2009) 140-8.

P.J. Barnes, R.A. Dweik, A.F. Gelb, P.G. Gibson, S.C.George, H. Grasemann et al., Exhaled nitric oxide in pulmonary diseases: a comprehensive review, Chest. 138 (2010) 682-692.

R. Aljhni, F. Ibrahim, Y.C. Guillaume, C. Andre, Reactive oxygen species and nitric oxide effect on the steroid hormone binding with serum albumin, Journal of Pharmaceutical and Biomedical Analysis. 62 (2012) 129-134.

R. D'Souza, M.K. Gill-Sharma, S. Pathak, N. Kedia, R. Kumar, N. Balasinor, Effect of high intratesticular estrogen on the seminiferous epithelium in adult male rats, Mol. Cell. Endocrinol. 241 (2005) 41-48.

R. Ekins, The science of free testosterone measurement, Proc. UK NEQAS meeting. 3 (1998) 35-39.
R. K. Sharma, A. Agarwal, Role of reactive oxygen species in male infertility, Urology. 48 (1996) 835850.

R.E. Gore-Langton, D.T. Armstrong, Follicular steroidogenesis and its control. In The physiology of reproduction, ed. E. Knobil, and J.D. Neill, New York: Raven. (1988) 331-385.

S. Benoff, A. Jacob, I.R. Hurley, Male infertility and environmental exposure to lead and cadmium, Hum. Reprod. Update. 6 (2000) 107-121.

S. Chouhana, S. K. Yadava, J. Prakasha, S. Westfalla, A. Ghoshb, N. K. Agarwalc, S. P. Singha, Increase in the expression of inducible nitric oxide synthase on exposure to Bisphenol A: A possible cause for decline in steroidogenesis in male mice, Environmental Toxicology and Pharmacology, 2014.

S. De Sio, T. Casale, M.V. Rosati, et al., Correlation between urinary Nickel and FSH plasma values in workers occupationally exposed to urban stressors, Prevent Res. 3 (4) (2013) 263-279.

S. Telisman, J. Jurasovic, Cadmium in the blood and seminal fluid of exposed adult male subjects, Int Arch Occup Environ Health. 70 (1997) 243-48.

S. Telisman, J. Jurasovic, J. Pongracic, Relationships between seminal fluid lead and Characteristic indicators of lead exposure in men, Heavy metals. 1 (1993) 14-17.

S.E. Chia, B. Xu, C.N. Ong, F.M. Tsakok, S.T. Lee, Effect of cadmium and cigarette smoking on human semen quality, International journal of fertility and menopausal studies. 39 (5) (1994) 292-298.

T.O. Abney, The potential roles of estrogens in regulating Leydig cell development and function: a review Steroids, 64 (1999) 610-617.

U.M. Joshi, et al., A sensitive specific enzyme immunoassay for serum testosterone, Steroids 34 (1979) 35 .

W. Torjussen, H. Zachariasen, I. Andersen, Cigarette smoking and nickel exposure, J. Environ. Monit. 5 (2) (2003) 198-201.

W.H. Yu, V. Rettori, S. Karanth, A. Walczewska, C. Mastronardi, S.M. McCann, The role of nitric oxide in reproduction, Braz. J. Med. Biol. Res. 32 (11) (1999) 1367-79. 